\title{
PENGARUH KONSUMSI MINUMAN MADU HUTAN TERHADAP TINGKAT KEASAMAN pH SALIVA PADA MAHASISWA PRODI D-IV ALIH JENJANG JURUSAN KEPERAWATAN GIGI POLTEKKES MAKASSAR ANGKATAN 2017
}

\author{
Asridiana, Ernie Thioritz, Hariana Lust
}

\begin{abstract}
ABSTRAK
Sebelum ditemukannya gula, madu telah digunakan sebagai minuman manis dan sebagai bahan pemberi rasa manis. Madu mengandung glukosa, fruktosa, serta sukrosa. Walaupun madu mengandung sukrosa rendah, madu tetap saja merupakan larutan karbohidrat yang mengandung gula dan dapat menyebabkan $\mathrm{pH}$ saliva menurun. Dalam penelitian ini yang digunakan adalah madu hutan. Penelitian dilaksanakan di Jurusan Keperawatan Gigi Poltekkes Makassar. Jumlah sampel dalam penelitian ini sebanyak 38 orang. Penelitian dilaksanakan pada bulan Oktober 2018 - Januari 2019. Pengambilan data menggunakan lembar observasi, $\mathrm{pH}$ meter dan pembagian Informed Consent. Jenis penelitian yang digunakan adalah Quasi Eksperimen. Penelitian menggunakan rancangan Pretest Posttest Control Group dengan menggunakan teknik Total Sampling. Data diolah dengan menggunakan SPSS dengan analisis paired T-Test. Rata-rata tingkat keasaman pH saliva sebelum mengkonsumsi minuman madu hutan adalah 7.05 dan setelah mengkonsumsi minuman madu hutan adalah 6.79 atau mengalami penurunan sebesar 0.26 menjadi lebih asam.
\end{abstract}

Kata Kunci: Keasaman, Madu Hutan, pH Saliva

\section{PENDAHULUAN}

Madu telah dikenal oleh manusia sejak abad keempat masehi dan dianggap sebagai bahan pemanis pertama. Sebelum ditemukan gula, madu telah digunakan sebagai minuman manis dan sebagai bahan pemberi rasa manis. Cairan kental dan manis ini juga kerap digunakan sebagai olesan roti. Cairan madu itu sendiri berasal dari lebah madu (Apis mellifera) dan tanaman pada bagian bunga dan pucuk daun. (Republika Online, 2006)

Dalam dunia medis, penggunaan madu sebagai obat sudah dimulai sejak zaman Yunani dan Mesir Purba. Saat itu di Mesir, madu merupakan salah satu dari 500 obat terpopuler. Madu berbeda dengan gula. Madu merupakan food supplement alami yang berkhasiat. Madu mengandung berbagai jenis vitamin, asam amino, macam-macam mineral dan 100 jenis zat yang bermanfaat untuk kesehatan. Karena kandungannya, tak heran jika madu bisa digunakan untuk pengobatan dan suplemen bagi mereka yang tengah berdiet, selain itu, madu juga mengandung monosacharida yang terdiri atas glukosa dan fruktosa, serta sukrosa dengan konsentrasi yang rendah. Oleh karena sukrosa dikenal sebagai sumber penyebab terjadinya karies gigi, sedangkan madu diketahui mengandung sukrosa rendah maka mulai dipikirkan kemungkinan menggunakan bahan alternative yang dapat digunakan sebagai bahan pengganti sukrosa adalah madu. Walaupun mengandung sukrosa rendah, madu tetap saja merupakan larutan karbohidrat yang mengandung gula dan dapat menyebabkan $\mathrm{pH}$ saliva menurun.

Saliva merupakan faktor yang penting dalam rongga mulut. Saliva mempunyai fungsi fisiologis yaitu membersihkan, pengaruh buffer, melindungi permukaan enamel dan membantu dalam pencernaan karbohidrat. Adanya 
rangsangan menyebabkan laju aliran saliva meningkatkan sekaligus menyebabkan komponen biokarbonat saliva semakin tinggi dan pada akhirnya akan meningkatkan $\mathrm{pH}$. Akibat dari aliran yang meningkat, hasil-hasil metabolic bakteri, zat-zat toksis bakteri akan larut dan tertelan sehingga keseimbangan lingkungan mulut akan terjaga. (Garant, 2003). Hasil penelitian yang dilakukan oleh Cerry Puspa Sari di FKG UI pada tahun 2008, menyatakan bahwa terjadi penurunan pada nilai viskositas, $\mathrm{pH}$ dan kapasitas dapar saliva setelah mengkonsumsi air madu dan air gula sukrosa.

Penelitian mengenai saliva masih belum jauh terungkap, padahal saliva memiliki peran yang cukup penting dalam mempengaruhi terjadinya proses karies. Oleh karena itu penulis tertarik untuk ikut meneliti tentang pengaruh konsumsi minuman madu hutan terhadap tingkat keasaman $\mathrm{pH}$ saliva.

Penelitian ini akan dilakukan pada mahasiswa Jurusan Keperawatan Gigi Poltekkes Kemenkes Makassar yang terletak di jalan Monumen Emmy Saelan III No.2, Makassar. Jurusan keperawatan gigi merupakan salah satu Jurusan di Politeknik Kesehatan Kementerian Kesehatan Makassar yang bertujuan untuk mencetak tenaga keperawatan gigi yang unggul dalam bidang pelayanan asuhan keperawatan gigi, membantu program pemerintah dengan adanya peningkatan status kesehatan gigi dan mulut.

\section{METODE PENELITIAN}

Jenis penelitian yang digunakan adalah penelitian eksperimen semu / quasi experiment. Rancangan penelitian menggunakan rancangan Pretest Posttest Control Group. Populasi dalam penelitian ini adalah seluruh Mahasiswa Prodi D-IV Alih Jenjang Jurusan Keperawatan Gigi Poltekkes Kemenkes Makassar angkatan 2017 yang berjumlah 38 orang. Sampel dalam penelitian ini berjumlah 38 orang. Sampel dalam penelitian ini diambil menggunakan teknik Total Sampling. Sampel yang diambil berjenis kelamin laki-laki dan perempuan yang pada saat pemeriksaan tidak sedang berpuasa dan tidak sedang menstruasi untuk sampel berjenis kelamin perempuan.bSampel tidak mengidap penyakit Diabetes mellitus dan tidak memiliki banyak karies.

Penelitian ini akan dilaksanakan di Jurusan Keperawatan Gigi Poltekkes Kemenkes Makassar. Penelitian ini rencananya berlangsung selama empat bulan, dimulai pada bulan Oktober 2018 - Januari 2019. Data diolah dengan menggunakan SPSS dengan analisis Uji T-Test.

Instrumen yang digunakan dalam penelitian ini adalah Lembar pemeriksaan, Informed Consent, ATK, Pot Penampungan Saliva, pH Meter. Bahan yang digunakan dalam penelitian ini adalah Madu hutan, Saliva, Aquades, Masker, Sendok plastik, Handschoen, Tissue dan Kapas.

\section{Penilaian pH Saliva}

1. $\mathrm{pH}$ yang nilainya kurang dari 7 maka saliva tersebut bersifat asam.

2. $\mathrm{pH}$ yang nilainya 7 maka saliva tersebut bersifat netral.

3. $\mathrm{pH}$ yang nilainya lebih dari 7 maka saliva tersebut bersifat basa. 


\section{Prosedur Penelitian}

1. Responden diinstruksikan untuk tidak makan dan minum 1 jam sebelum pengambilan saliva.

2. Tidak menelan dan mengunyah selama pengumpulan saliva.

3. Mengukur dan mencatat $\mathrm{pH}$ saliva responden sebelum dilakukan perlakuan.

4. Responden masing-masing diberikan 1 sendok minuman madu. Responden memasukkan madu ke dalam rongga mulut kemudian ditahan di dalam mulut selama 60 detik kemudian ditelan

5. Responden diinstruksikan untuk duduk sambil menundukkan kepala kurang lebih $45^{\circ}$ terhadap lantai.

6. Metode pengumpulan saliva yang digunakan adalah metode Passive Drool yaitu dengan cara mulut agak dibuka kemudian saliva dibiarkan mengalir kedalam wadah saliva, apabila saliva sukar keluar dapat dibantu dengan lidah mendorong saliva masuk kedalam wadah saliva.

7. Pengumpulan saliva dilakukan selama 60 detik. Setelah itu $\mathrm{pH}$ saliva diukur menggunakan $\mathrm{pH}$ meter dan hasilnya dicatat.

\section{HASIL PENELITIAN}

Karakteristik responden dalam penelitian ini berupa karakteristik jenis kelamin dan umur. Berikut ini adalah distribusi frekuensi responden berdasarkan jenis kelamin:

Tabel 1 Distribusi Karakteristik Responden berdasarkan Jenis Kelamin

\begin{tabular}{|c|c|c|}
\hline Jenis Kelamin & $\mathbf{n}$ & $\%$ \\
\hline Pria & 6 & $15.8 \%$ \\
\hline Wanita & 32 & $84.2 \%$ \\
\hline Jumlah & 38 & $100 \%$ \\
\hline
\end{tabular}

Sumber: Data Primer Tahun 2019

Tabel di atas menunjukkan bahwa jumlah responden wanita mendominasi dalam $84.2 \%$ responden berjenis kelamin wanita dan penelitian ini.

$15.8 \%$ berjenis kelamin pria. Tampak bahwa

Tabel 2 Distribusi Karakteristik Responden berdasarkan Umur

\begin{tabular}{|c|c|c|c|}
\hline Umur & $\mathbf{n}$ & $\%$ & $\begin{array}{c}\text { Rata-rata pH } \\
\text { saliva }\end{array}$ \\
\hline $21-30$ & 18 & $47.36 \%$ & 6.81 \\
\hline $31-40$ & 20 & $52.64 \%$ & 6,71 \\
\hline Jumlah & 38 & $100 \%$ & \\
\hline
\end{tabular}

Sumber: Data Primer Tahun 2019 
Tabel di atas menunjukkan bahwa responden dengan rentang umur antara 21-30 tahun sebanyak 18 orang (47.36\%) dengan rata-rata $\mathrm{pH}$ saliva 6.81 , responden dengan rentang umur antara 31-40 tahun sebanyak 20 orang (52.64\%.) dengan rata-rata $\mathrm{pH}$ saliva 6.71. Berikutnya adalah hasil analisis univariat berupa tabel distribusi frekuensi $\mathrm{pH}$ saliva sebelum dan setelah pemberian minuman madu hutan:

Tabel 3 Distribusi pH Saliva Pada Responden Sebelum Diberi Minuman Madu Hutan

\begin{tabular}{|c|c|c|}
\hline pH saliva & n (Jumlah) & Persentase (\%) \\
\hline Asam & 13 & $34.2 \%$ \\
\hline Netral & 3 & $7.9 \%$ \\
\hline Basa & 22 & $57.9 \%$ \\
\hline Jumlah & $\mathbf{3 8}$ & $\mathbf{1 0 0} \%$ \\
\hline
\end{tabular}

Sumber: Data Primer, tahun 2019

Pada tabel 3 menunjukkan bahwa sebelum mengkonsumsi madu hutan sebanyak 13 orang $(34.2 \%)$ responden memiliki $\mathrm{pH}$ saliva dengan kriteria asam, 3 orang (7,9\%) responden memiliki $\mathrm{pH}$ saliva dengan kriteria netral, dan 22 orang $(57.9 \%)$ responden memiliki $\mathrm{pH}$ saliva dengan kriteria basa.

Tabel 4 Distribusi pH Saliva Pada Responden Setelah Diberi Minuman Madu Hutan

\begin{tabular}{|c|c|c|}
\hline pH saliva & n (Jumlah) & Persentase (\%) \\
\hline Asam & 28 & $73.7 \%$ \\
\hline Netral & 4 & $10.5 \%$ \\
\hline Basa & 6 & $15.8 \%$ \\
\hline Jumlah & $\mathbf{3 8}$ & $\mathbf{1 0 0} \%$ \\
\hline
\end{tabular}

Sumber: Data Primer, tahun 2019

Pada tabel 4 menunjukkan bahwa setelah mengkonsumsi madu hutan sebanyak 28 orang $(73.7 \%)$ esponden memiliki pH saliva dengan kriteria asam, 4 orang (10.5\%) responden memiliki $\mathrm{pH}$ saliva dengan kriteria netral, dan 6 orang (15.8\%) responden memiliki $\mathrm{pH}$ saliva dengan kriteria basa. 
Tabel 5 Distribusi Frekuensi Responden Berdasarkan Rata-Rata Nilai pH Saliva

\begin{tabular}{|c|c|c|c|}
\hline \multirow{2}{*}{ Variabel } & \multicolumn{2}{|c|}{ pH Rata-Rata Saliva } & \multirow{2}{*}{ Selisih } \\
\cline { 2 - 3 } & Sebelum & Sesudah & \\
\hline \multirow{2}{*}{$\begin{array}{c}\text { Mengkonsumsi Minuman Madu } \\
\text { Hutan }\end{array}$} & 7.05 & 6.79 & 0.26 \\
\hline
\end{tabular}

Pada tabel di atas tampak bahwa sebelum diberikan minuman madu hutan, ratarata $\mathrm{pH}$ saliva sampel adalah 7.05 dan ratarata $\mathrm{pH}$ saliva setelah diberikan minuman madu hutan adalah 6.79, dimana terdapat selisih penurunan $\mathrm{pH}$ saliva sebesar 0.26 menjadi lebih asam. Selanjutnya dilakukan uji analisis paired-sample $\mathrm{T}$ dimana uji ini berfungsi untuk menganalisis pengaruh pemberian perlakuan pada sampel yang sama. Sampel diberi perlakuan yaitu diberikan minuman madu hutan dimana peneliti melakukan pengukuran $\mathrm{pH}$ saliva sebelum dan setelah pemberian minuman madu hutan. Pada uji paired -sample $T$ didapat nilai $\mathrm{p}$ sebesar 0,002, maka dapat disimpulkan pada tingkat kepercayaan 95\% terdapat perbedaan rata-rata yang signifikan antara $\mathrm{pH}$ saliva sebelum dan setelah pemberian minuman madu hutan.

\section{PEMBAHASAN}

Nilai rata-rata $\mathrm{pH}$ saliva responden mengalami penurunan dari 7,06 menjadi 6,79 namun tidak mencapai nilai $\mathrm{pH}$ kritis $(\mathrm{pH}<5.5)$. Hal ini cenderung berlawanan dengan teori yang diungkapkan oleh Stephan, bahwa 10 menit setelah konsumsi glukosa maka akan terjadi penurunan $\mathrm{pH}$ hingga mencapai nilai $\mathrm{pH}$ kritis ( $\mathrm{pH}<5.5)$. (Dawes, 1996)

Perbedaan ini mungkin terjadi karena perlakuan yang dilakukan dalam penelitian ini sedikit berbeda dengan percobaan yang dilakukan oleh Stephan. Stephan melakukan percobaan dengan kumur glukosa $10 \%$ sehingga didapatkan penurunan nilai $\mathrm{pH}$ plak mencapai 5.5 dalam waktu 10 menit setelah perlakuan. Sementara pada penelitian ini, subjek tidak berkumur melainkan hanya menahan selama 60 detik madu di dalam rongga mulut kemudian ditelan sehingga waktu pemaparan madu di dalam rongga mulut lebih singkat. Selain itu, pengukuran yang dilakukan bukan terhadap $\mathrm{pH}$ plak yang lebih stabil, melainkan terhadap $\mathrm{pH}$ saliva yang mudah berubah. Dengan demikian, mungkin saja nilai $\mathrm{pH}$ saliva yang diberikan sudah dinetralkan oleh kerja kapasitas dapat saliva subjek dalam rentang waktu 10 menit sebelum dilakukannya pengukuran.

Hasil tersebut berbanding terbalik dengan penelitian yang dilakukan oleh Fione (2013) yang menunjukkan hasil peningkatan rata-rata nilai $\mathrm{pH}$ saliva responden dari 6.257 menjadi 7.043. Hal ini disebabkan karena di dalam madu terdapat kandungan mineral yang dapat meningkatkan produksi saliva atau 
cairan ludah sehingga dapat menjaga keseimbangan $\mathrm{pH}$ saliva di dalam rongga mulut. (Purbaya, 2007)

Namun penurunan nilai $\mathrm{pH}$ saliva menjadi lebih asam sesuai dengan hasil penelitian yang dilakukan oleh Dwi Eni Purwati (2016) yang menyatakan bahwa nilai $\mathrm{pH}$ saliva pada kelompok eksperimen sesudah mengkonsumsi minuman madu mengalami penurunan dari sebelum mengkonsumsi minuman madu, yaitu dari 6.93 menjadi 6.64 dengan nilai sig. 005, yang menunjukkan adanya perbedaan yang bermakna antara nilai pH saliva siswa siswi kelas III, IV dan V SD Muhammadiyah Sambisari sebelum dan sesudah mengkonsumsi minuman madu. Perbedaan ini disebabkan karena menurunnya nilai $\mathrm{pH}$ saliva siswa setelah mengkonsumsi minuman madu tetapi masih dalam standar normal nilai pH saliva yaitu 6.93 menjadi 6.64. Sesuai dengan hasil penelitian yang dilakukan oleh Sari (2008) yang menyatakan bahwa nilai $\mathrm{pH}$ rata-rata setelah mengkonsumsi madu menunjukkan adanya penurunan, yaitu dari 7.40 menjadi 6.94. Meskipun demikian, penurunan nilai $\mathrm{pH}$ ini ternyata tidak mencapai nilai $\mathrm{pH}$ kritis $(\mathrm{Ph}<5.5)$. Penurunan nilai $\mathrm{pH}$ ini dikarenakan setelah saliva terstimulasi oleh air madu, terjadi pemecahan karbohidrat menjadi asam laktat. Akibatnya, terjadi penurunan $\mathrm{pH}$ di dalam rongga mulut.

Faktor lainnya yang mungkin menyebabkan turunnya nilai $\mathrm{pH}$ saliva setelah mengkonsumsi madu adalah karena madu memiliki nilai $\mathrm{pH}$ yang asam. Menurut Putri (2014) nilai pH madu rata-rata adalah 3.2-4,5. Nilai $\mathrm{pH}$ madu yang cukup rendah ini disebabkan oleh beberapa kandungan asam organik yang terdapat dalam madu, seperti asam asetat, asam format, asam glukonat, asam oksalat, asam piroglutamat, asam suksinat, asam laktat, asam malat, asam glikolat, asam butirat, asam sitrat, asam piruvat dan asam tartrat. (Fione, dkk. 2013)

Namun penelitian ini didukung oleh Meily Zuraida (2007) yang dalam penelitiannya tentang perbedaan $\mathrm{pH}$ saliva terhadap konsumsi madu yang menunjukkan penurunan $\mathrm{pH}$ saliva dari 7.0 menjadi 6.8 dengan nilai kemaknaan sebesar 1,000 ( $p>0,05)$ yang artinya tidak ada hasil yang signifikan setelah mengkonsumsi madu, tetapi penurunan $\mathrm{pH}$ saliva tersebut tidak sampai mencapai titik kritis $(\mathrm{pH}<5,5)$. Artinya dalam penelitian ini kapasitas buffer responden masih efektif dan ditunjang oleh jumlah kuman yang berkurang.

Berdsarkan faktor-faktor di atas dapat dijelaskan bahwa konsumsi makanan atau minuman tertentu bukan menjadi satu-satunya faktor terjadinya perubahan $\mathrm{pH}$ saliva. Faktor yang menyebabkan terjadinya perubahan pada $\mathrm{pH}$ saliva antara lain rata-rata kecepatan aliran saliva, mikroorganisme rongga mulut dan kapasitas buffer saliva. Selain itu ada faktorfaktor yang mempengaruhi pembentukan asam, antara lain: jenis karbohidrat yang terdapat dalam diet, konsentrasi karobohidrat dalam diet, jenis dan jumlah bakteri di dalam plak, keadaan fisiologi bakteri tersebut dan $\mathrm{pH}$ di dalam plak.

Konsumsi obat-obatan tertentu serta ritme biologis tubuh juga perlu dikaji sebelum pengambilan sampel pada responden. Obatobatan antidepresan, antipsikotik, transquilizer, antihistamin, hipnotika, antihipertensi, antikholinergi, diuretika, anti parkinson, dan 
obat pengurang nafsu makan. Jika obat-obatan tersebut digunakan untuk waktu lebih dari satu minggu, maka harus diambil langkah-langkah untuk melindungi gigi dari serangan karies. (Edwina, 1991)

Dalam penelitian ini responden dengan usia antara 21-30 tahun memiliki ratarata $\mathrm{pH}$ saliva 6.81 dan responden dengan usia antara 31-40 tahun memiliki rata-rata $\mathrm{pH}$ saliva 6.71. Artinya faktor umur juga berpengaruh dalam penurunan $\mathrm{pH}$ saliva. Keadaan ini disebabkan oleh adanya perubahan atropi pada kelenjar saliva sesuai dengan pertambahan umur yang akan menurunkan produksi saliva dan mengubah komposisinya sedikit. Seiring dengan meningkatnya usia, terjadi proses aging. Terjadi perubahan dan kemunduran fungsi kelenjar saliva, dimana kelenjar parenkim hilang yang digantikan oleh jaringan lemak dan penyambung, lining sel duktus intermediate mengalami atropi. Keadaan ini mengakibatkan pengurangan jumlah aliran saliva. (Edwina, 1991)

Selain itu latar belakang pendidikan atau pengetahuan responden tentang kesehatan gigi dan mulut juga menjadi salah satu faktor yang harus diperhatikan. Responden dalam penelitian ini adalah mahasiswa Jurusan Keperawatan Gigi yang memiliki pengetahuan yang baik tentang oral hygiene. Hal ini sesuai pendapat Notoatmodjo (2005) yang mengatakan tingkat pengetahuan akan mempengaruhi tingkat penguasaan responden terhadap derajat kesehatannya, karena dalam pendidikan terjadi proses pembelajaran yang selanjutnya akan mempengaruhi perilaku seseorang dalam melakukan tindakan pemeliharaan dan peningkatan kesehatan.

\section{KESIMPULAN}

Berdasarkan hasil penelitian yang telah dilakukan pada 38 responden tentang pengaruh konsumsi minuman madu hutan terhadap tingkat keasaman $\mathrm{pH}$ saliva pada mahasiswa prodi D-IV Alih Jenjang Jurusan Keperawatan Gigi Poltekkes Makassar angkatan 2017, dapat disimpulkan bahwa:

1. Terdapat pengaruh terhadap $\mathrm{pH}$ saliva setelah pemberian minuman madu hutan.

2. Rata-rata tingkat keasaman $\mathrm{pH}$ saliva sebelum mengkonsumsi minuman madu hutan adalah 7.05 dan setelah mengkonsumsi minuman madu hutan adalah 6.79 .

\section{SARAN}

1. Perlu diadakan penelitian lebih lanjut dari penelitian di atas dengan jumlah sampel yang lebih banyak.

2. Dianjurkan kepada masyarakat untuk selalu menjaga kualitas saliva dengan cara menyikat gigi secara rutin, banyak minum air putih dan berkumur setelah mengkonsumsi madu atau aneka jenis makanan lainnya.

\section{DAFTAR PUSTAKA}

Aden, R. 2010. Manfaat \& Khasiat Madu Keajaiban Sang Arsitek Alam. Yogyakarta: Hanggar Kreator

Amerongen A van Nieuw. 1991. Ludah dan Kelenjar Ludah. Alih Bahasa. Abyo R. Gadjah Mada University Press. Yogyakarta

Dawes C. 1996. Factors Influencing Salivary Flow Rate And Composition. In Edgar WM. O'Mullane DM (ed). Saliva and 
Oral Health. $2^{\text {nd }}$ ed. London: British Dental Association.

Edwina A.M, Joyston B.S. Dasar-dasar karies penyakit dan penanggulangannya. Editor: Narlan Sumawinata, Safrida Faruk. Jakarta: EGC; 1991.

Faisol Al Fady. 2015. Madu dan Luka Diabetik. Gosyen Publishing. Yogyakarta

Fione, Roose, V., Maramis, J.L, dan Meylandri, D.P., 2013. Pengaruh Berkumur Dengan Larutan Madu Terhadap $\mathrm{pH}$ Saliva Pada Wanita Kaum Ibu Jemaat Getsemani Desa Senduk Kecamatan Tombariri. Jurnal Jurusan Keperawatan Gigi Poltekkes Kemenkes Manado JIK. 7(2)

Firdaus Chandra. 2006. Pengaruh stimulus pengunyahan dan pengecapan terhadap kecepatan aliran dan $\mathrm{pH}$ saliva. Fakultas Kedokteran Gigi Universitas Hasanuddin Makassar.

Garant, Philias R. 2003. Oral Cell and Tissues. Qiuntessence Publishing Co.

Haviva, A.B. 2011. Dahsyatnya Mukjizat Madu untuk Kesehatan, Kecantikan dan Kecerdasan. Jogjakarta: DIVA Press.

Ilyas M., Yusri M. 2007. Perbedaan kadar kalsium dalam saliva sebelum dan sesudah mengkonsumsi minuman ringan yang mengandung asam bikarbonat. Jurnal Kedokteran Gigi vol. 16 no.2

Intanwidya, Y. 2005. Analisa Madu dari Segi Kandungannya Berikut Khasiatnya Masing-Masing. [Online] Available from: $\quad$ http://www.mailarchive.com/forum@alumniakabogor.net/msg01046.html. Accessed September.

Joshi SR, Pechhacker H, William A, Von der Ohe W. 1999. Phisico-Chemical Characteristics of Apis dorsata, A.cerana, and A. Mallifera honey. Hal. 2000.
Lugaz $\mathrm{O}$, Phillias AM, Boireau-Ducept $\mathrm{N}$ and Faurion A. 2005. Time-Intensity Evaluation of Acid Taste in Subjects with Saliva High Flow and Low Flow Rates for Acids of Various Chemical Properties. Chemical Sence. 30(1).

Minasari. 1999. Peranan saliva dalam rongga mulut. Majalah Kedokteran Gigi Universitas Sumatera Utara.

Molan PC. 2001. The potential of honey to promote oral wellness. Gen Dent. Nov-Dec: (49) 6.

Namias, N. 2003. Honey in The Management of Infection. Miami: De Witt Dughtry Family Department of Surgery, University Scholl of Medicine.

Nanci A. 2008. Ten cate's oral Hystology: development, structure, and function. St. Louis : Mosby Elsevier

Navazesh M, Kumar SK. 2008. Measuring salivary flow: challenges and opportunities. J Am Dent Assoc

Notoatmodjo, s, 2005, Promosi kesehatan teori dan Aplikasi, Jakarta : PT Rineka Cipta

Republika online. 2018. Madu untuk Sakit Tenggorok. [Online] Available from: http://www.republika.co.id. Accessed September.

Sari, C.P. 2018. Perbandingan Nilai Viskositas, $\mathrm{pH}$ dan Kapasitas Dapar Saliva Setelah Mengkonsumsi Air Madu Dan Air Gula Sukrosa. Skripsi Program Studi Kedokteran Gigi Universitas Indonesia. Jakarta.

Wirakusumah PA. 2010. Sehat Cara Al-Qur'an dan Hadist. Penerbit Hikmah. Bandung.

Wong DT. 2008. Salivary Diagnostic. lowa: Wiley-Blackwell

Zuraida Meily. 2007. Perbedaan $p H$ saliva terhadap konsumsi madu dan permen coklat. Fakultas Kedokteran Gigi Universitas Hasanuddin Makassar. 